\title{
Unmanipulated Peripheral Blood Stem Cell Transplantation with non-TBI Myeloablative Conditioning Regimen from Haploidentical and Unrelated versus Related Donors for Acute Leukemia in Children, Adolescents and Young Adults (CAYA): A Competing Risk Analysis
}

Seied Asadollah Mousavi

Tehran University of Medical Sciences

Tahereh Rostami

Tehran University of Medical Sciences

Azadeh Kiumarsi ( $\square$ akiumarsi@sina.tums.ac.ir)

Tehran University of Medical Sciences https://orcid.org/0000-0001-5492-8830

Amir Kasaeian

Tehran University of Medical Sciences

Mohammadreza Rostami

Tehran University of Medical Sciences

Neda Alijani

Tehran University of Medical Sciences

Soroush Rad

Tehran University of Medical Sciences

Mohammad Vaezi

Tehran University of Medical Sciences

Hosein Kamranzadeh Feumani

Tehran University of Medical Sciences

Davood Babakhani

Tehran University of Medical Sciences

Tanaz Bahri

Tehran University of Medical Sciences

Sahar Tavakoli Shiraji

Tehran University of Medical Sciences

Maryam Barkhordar

Tehran University of Medical Sciences 


\section{Research Article}

Keywords: Acute leukemia, Allogeneic hematopoietic stem cell transplantation, Matched related donors, Unrelated donors, Haploidentical donors

Posted Date: October 28th, 2021

DOl: https://doi.org/10.21203/rs.3.rs-895707/v1

License: (c) (i) This work is licensed under a Creative Commons Attribution 4.0 International License.

Read Full License 


\section{Abstract}

\section{Background}

Allogeneic hematopoietic stem cell transplantation (HSCT) is the only potentially curative treatment for acute leukemia. Many different parameters have significant impact on the final results of HSCT such as donor type, stem cell source, and the implemented conditioning regimen. In the absence of an HLAmatched related donor, unrelated donors or haploidentical donors are possible alternatives for patients with an indication to HSCT. In order to compare the outcomes of HSCT from different donor types, in this single-center study, using a radiation-free MAC regimen, we compared the results of unmanipulated peripheral blood stem cell transplantation (PBSCT) from matched and mismatched related and unrelated donors with haploidentical donors in the children, adolescents and young adults (CAYA) affected by acute leukemia.

\section{Methods}

In this retrospective study, since 2014 to 2021 , the outcome of CAYA patients with acute leukemia who had undergone peripheral blood T cell-replete HSCT from haploidentical donors versus unrelated donors (including $10 / 10$ or $9 / 10$ HLA-matched) versus related donors (including $10 / 10$ or 9/10 HLA-matched) were evaluated. The HSCT was based on a radiation-free MAC regimen including Busulfan and Cyclophosphamide. The GvHD prophylaxis was based on the administration of Cyclosporine A in all patients, plus rabbit anti-human thymocytes globulins in unrelated and haploidentical donors and post transplantation cyclophosphamide in haploidentical donors. Adjusted multivariable proportional hazard Cox and competing risk analyses were performed.

\section{Results}

Median follow up time was 28.7 months (95\% Cl: 21.9-34.9). Three-year overall survival rate (OS) and GvHD-free/relapse-free survival (GFRFS) rate was $68.81 \%$ (95\% Cl: $60.08 \%-76.01 \%)$ and $44.19 \%$ (95\% Cl: $35.52 \%-52.49 \%$ ), respectively. Patients who had undergone HSCT from an unrelated donor had the lowest OS and GFRFS compared to other donor types. The 3-years NRM in all patients was $7.84 \%(95 \% \mathrm{Cl} 4.36$ 12.62). Adjusted multivariable modeling of OS showed that the hazard of death in patients who had undergone HSCT from an unrelated donor, was 3.6 times more than patients who underwent HSCT from their haploidentical donors $(P=0.05)$. Likewise, the hazard of NRM after HSCT from unrelated donors was 6 times more than haploidentical donors $(P=0.002)$. However, the relapse incidence was not significantly different between the two mentioned groups.

\section{Conclusions}

In this study, HSCT from haploidentical donors was associated with superior survival rates compared to HSCT from unrelated donors. So haploidentical peripheral blood derived HSCT could be a practical and valuable clinical option that offers CAYA patients with acute leukemia needing HSCT and lacking matched available donors, a reasonable opportunity for disease control. 


\section{Introduction}

Allogeneic hematopoietic stem cell transplantation (HSCT) is the only available curative option for acute leukemia nowadays. Many different parameters have significant impact on the final results of HSCT, especially on the more recently defined graft-vs-host disease (GvHD)-free/relapse-free survival (GFRFS) rate, including the pre-HSCT characteristics such as disease profile at diagnosis and the disease status at the time of transplant, and also the peri-HSCT factors, i.e. donor type, stem cell source, the implemented conditioning regimen and the potential complications. In an effort to reduce relapse rates after HSCT, the use of myeloablative conditioning (MAC) regimens with higher intensities using busulfan or total body irradiation (TBI) has shown promising results. ${ }^{1}$ Given the higher vulnerability of younger patients to adverse effects of irradiation, MAC regimens without TBI are preferred. ${ }^{2}$ Moreover, in view of the relative unwieldiness for bone marrow collection together with the potentially augmented graft versus leukemia (GvL) effect, peripheral blood (PB) is preferred as the source of stem cells for allogeneic HSCT ever more. On the other hand, the increasing number of transplants from human leukocyte antigen (HLA)haploidentical donors in patients with acute leukemia due to the absence of a suitable related or unrelated HLA-matched donor, has raised the necessity of understanding if HSCT outcomes with this approach are similar to those of more consolidated approaches. Lately, more than a few reports have shown comparable outcomes between HSCT from haploidentical donors and historical HLA-matched related or unrelated donors. ${ }^{3}$ Hence, adding up to the records regarding the comparison of different donor types could be a guide for the upcoming therapeutic strategies. To address this inquiry, in this singlecenter study, using a radiation-free MAC regimen, we compared the results of unmanipulated peripheral blood stem cell transplantation (PBSCT) from matched and mismatched related and unrelated donors with haploidentical donors in children, adolescents and young adults (CAYA) affected by acute leukemia.

\section{Subjects And Methods}

\section{Patients}

Our study included patients undergone first allogenic HSCT for acute leukemia in CAYA HSCT department of Research Institute for Oncology, Hematology and Cell Therapy (RIOHCT), Tehran, Iran, between January 2014 and January 2021. All data were retrieved retrospectively from clinical records according to the policy approved by the Committee on Medical Ethics of Tehran University of Medical Sciences (TUMS) and after obtaining informed consent from patients or their legal guardians.

In all patients and their donors, high-resolution HLA molecular typing for loci HLA-A, -B, -C, -DRB1, and DQB1 were performed. The first donor preference was a 10/10 HLA-matched related donor (MRD) or a 9/10 HLA-mismatched related donor (MMRD). If an MRD/MMRD was unavailable, an alternative donor including a 10/10 HLA-matched unrelated donor (MUD) or a 9/10 HLA-mismatched unrelated donor (MMUD) or a related haploidentical donor (Haplo) was chosen depending on the availability and accessibility. 
We proceeded to HSCT if the result of a pre-HSCT bone marrow examination pointed to morphologically complete remission (CR), regardless of the minimal residual disease status.

The HSCT was based on a radiation-free MAC regimen including Busulfan (a total dose of 3.2-4.8 $\mathrm{mg} / \mathrm{kg} /$ day according to patients' ideal body weight, from day -6 to -3 ) and Cyclophosphamide (60 $\mathrm{mg} / \mathrm{kg} /$ day, from day -2 to -1 ). The GvHD prophylaxis was based on the administration of Cyclosporine A (CsA) in all patients and a short course of Methotrexate in HSCT from matched and mismatched related and unrelated donors, plus rabbit anti-human thymocytes globulins (ATG-Thymoglobuline, Sanofi, $2.5 \mathrm{mg} / \mathrm{kg} /$ day, from days -3 to -1 ) in MMRD, MUD/MMUD and Haplo groups and a high dosage of PtCy $(40 \mathrm{mg} / \mathrm{kg} /$ day on days +3 and +4$)$ in the Haplo group. We only included patients receiving unmanipulated peripheral blood hematopoietic stem cells as graft source.

Considering the risk of CMV reactivation after HSCT, patients were classified into low risk (donor $[D]-/$ recipient $[R]-)$, intermediate risk (D+/R-), or high risk $(D-/ R+$ or $D+/ R+){ }^{4}$

\section{Definitions and endpoints}

The main purpose of this study was to compare the survival rates of acute leukemia patients who had undergone allogeneic HSCT from different donor types. Overall survival (OS) was defined as the probability of survival irrespective of the disease state at any point in time

GvHD-free/relapse-free survival (GFRFS) which is an end point more precisely reflective of health status and quality of life post transplantation, was defined as the probability of survival with complete disease remission, with sustained donor cell engraftment and with neither grade III-IV acute GvHD nor chronic GvHD requiring immunosuppressive treatment. ${ }^{5}$ Non-relapse mortality (NRM) was defined as the probability of death without the occurrence of relapse after HSCT. Relapse incidence (RI) was defined as the probability of having had a disease relapse.

Donor chimerism was determined at day $+15,+30,+60$ and +90 after HSCT, and then when clinically indicated, on whole bone marrow mononuclear cells by quantitative PCR of informative short tandem repeats in the donor and recipient. ${ }^{6}$ Sustained donor cell engraftment was defined as the presence of more than $0.5 \times 10^{9} / \mathrm{L}$ neutrophils and more than $20 \times 10^{9} / \mathrm{L}$ platelets for three consecutive days without transfusion support. Graft rejection was defined as a lack of initial engraftment of donor cell graft (primary) or loss of donor cell engraftment (secondary), independently from the peripheral cell blood count. Acute (aGvHD) and chronic GvHD (cGvHD) were diagnosed and graded according to the published criteria. ${ }^{7}$ The mentioned HSCT outcomes were compared between the three categorized groups of different donor types including HLA-matched (10/10) related and HLA-mismatched (9/10) related donors (MRD/MMRD), HLA-matched (10/10) unrelated and HLA-mismatched $(9 / 10)$ unrelated donors (MUD/MMUD) and HLA-haploidentical (Haplo) donors.

\section{Statistical analysis}


Patients followed-up beyond 36 months were censored for better comparison between groups because some sub-groups had shorter follow-up periods than the other sub-groups. Homogeneity between treatment pairs was evaluated using the Chi-square test or Fisher exact test for qualitative variables and Student's T-test or Wilcoxon rank-sum test for continuous variables. The endpoints were OS, GFRFS, relapse, and non-relapse mortality incidence. Kaplan-Meier curves were derived to determine OS and GFRFS, and were compared through the log-rank test. Median follow-up time was established with the reverse Kaplan-Meier method. After selection of baseline characteristics and clinical variables based on univariable Cox proportional hazards models, multivariable Cox proportional hazards models were fitted .

Variables in the multivariable OS and GFRFS were determined based on the P-values at or less than 0.2 in the univariable Cox proportional hazards models. The proportionality of hazards assumption was checked using the global proportionality of hazards test based on Schoenfeld residuals in each of the three multivariable models. There was no departure from the proportionality of hazards assumption in all multivariable models (results not shown). To account for the informative censoring in the presence of multiple endpoints, competing risks survival analysis was performed utilizing nonparametric methods using the cumulative incidence competing risk method. $\mathrm{Cl}$ of relapse and NRM were calculated by Gray's method. Death without relapse was considered as a competing event for relapse, and relapse was considered as a competing event for NRM. Fine-Gray proportional hazard regression model used to assess the effects of covariates on relapse incidence and NRM incidence. Like multivariable Cox PH regression, all variables with a P-value at or less than 0.2 in the univariable Fine-Gray proportional hazard regression were included in the corresponding multivariable analyses. A two-sided P-value of 0.05 or lower was considered to be statistically significant. Analyses were done with STATA version 16 and Packages "survival" and "cmprsk" in R software version 3.3.1.

\section{Results}

\section{Patients}

The study included 180 patients ( 120 males and 60 females) with a median age of 12 years (ranging from 4 months to 24 years) at the time of HSCT, and 123 (68.3\%) patients were transplanted $\leq 15$ years of age. Donor type was matched $(n=103)$ and mismatched $(n=2)$ relative including sibling $((n=94)$ and other relatives $(n=11)$ in a total of $105(58.3 \%)$ patients, matched $(n=20)$ and mismatched $(n=10)$ unrelated in a total of $30(16.7 \%)$ patients and haploidentical in $45(25 \%)$ patients. The patients' characteristics are summarized in table 1.

The median follow-up time of patients enrolled in the study and who were still alive at the end of the study was 28.7 months (range: 21.9-34.9). A total of 96 patients presented with B-cell lineage acute lymphoblastic leukemia (ALL), 22 with T lineage ALL and 62 patients with acute myeloblastic leukemia (AML). Totally, 12 patients suffered from Philadelphia chromosome-positive ALL. All patients were in complete morphologic remission before HSCT, among which a total of 93 (51.7\%) patients were transplanted in their first complete remission (CR1), 67 (37.2\%) patients in their second complete 
remission (CR2), and 20 (11.1\%) patients had experienced more than 2 times of relapse before HSCT. A pre-HSCT cytomegalovirus (CMV) serologic analysis showed that more than $90 \%$ of the patients were high risk (recipient [R]+, donor [D]+) for CMV reactivity after HSCT.

\section{Donor cell engraftment}

All (180/180) patients achieved neutrophil counts above $0.5 \times 10^{9} / \mathrm{L}$ at a median time of 11 (range: $\left.7-16\right)$ days. A total of 178 patients achieved platelet counts above $20 \times 10^{9} / \mathrm{L}$ with a median time of 11 (range: $0-130$ ) days, and 4 patients died before platelet engraftment (table 2). The median time for neutrophil and platelet engraftment in Haplo vs MUD/MMUD vs MRD/MMRD was 12.20 and 14.67 days vs 12.17 and 16.21 days vs 10.73 and 14.30 days, respectively. Two patients from the Haplo group experienced secondary graft failure following CMV reactivation with high viral load after HSCT; one patient was successfully rescued through second haploidentical HSCT from the same haploidentical sibling donor, whereas the other received a second allograft from the other parent with sustained engraftment and hematopoietic recovery.

\section{Acute and chronic GVHD}

Grade II to IV of aGvHD was developed in 70 (38.9\%) patients with a median time of 15 days after HSCT. Cumulative incidence of aGVHD at day 100 was highest in the MUD/MMUD group compared to Haplo and MRD/MMRD, but this difference was not statistically significant $[31.6 \%( \pm 11.8)$ versus $10.5 \%( \pm 7.0)$ versus $27.3 \%( \pm 6.0)$, respectively $(P=0.845)]$.

Among the 165 patients who survived more than 100 days after HSCT, 27 (15\%) patients experienced cGvHD and we observed a lower incidence of 3-year cGVHD in the haploidentical group compared to the MUD/MMUD group $[7.0 \%( \pm 5.0)$ versus $22.5 \%( \pm 10.3)$, respectively]. Table 2 represents the comparison of GvHD in three donor types.

\section{Relapse incidence (RI)}

The 1-year and 3-year RI of the entire study population was $20.47 \%(95 \% \mathrm{Cl} 14.66-26.97)$ and $33.85 \%$ (95\% Cl 25.81-41.98), respectively. The 3-year RI in patients of the Haplo group was higher compared to MUD/MMUD and MRD/MMRD: 40.95\% (95\% Cl 18.41-62.44) versus 32.94\% (95\% Cl 11.92-56.01) versus $33.17 \%$ (95\% Cl 23.64-42.99), respectively (table 3). This difference was not statistically significant $(\mathrm{P}=0.902)$. In the Cox analysis performed, in both univariable and multivariable analysis, RI was not significantly different among the three donor type groups (table 5). In adjusted multivariable modelling of $\mathrm{RI}$, the hazard of relapse in patient from the MUD/MMUD group was only $10 \%$ lower than patients from the Haplo group [HR=0.90 (95\% Cl 0.37-2.19), $\mathrm{P}=0.826]$.

\section{Survival rates and post-HSCT complications}

The 3-year OS and GFRFS rates for the entire study population were $68.81 \%(95 \% \mathrm{Cl} 60.08-76.01)$ and $44.19 \%$ (95\% Cl 35.52-54.49), respectively. Patients in the MUD/MMUD group had the lowest OS and 
GFRFS compared to other donor types (table 4). The 3-year OS rates were 73.58\% (95\% Cl 62.98-81.59), $54.21 \%$ (95\% Cl 29.61-73.49), and 64.18\% (95\% Cl 39.76-80.79) for MRD/MMRD, MUD/MMUD, and Haplo groups, respectively ( $\mathrm{P}=0.08)$; The 3-year GFRFS rates were $47.11 \%(95 \% \mathrm{Cl} 36.48-57.02), 30.89 \%(95 \% \mathrm{Cl}$ 10.70-53.80), and 42.46\% (95\% Cl 20.41-63.01) for MRD/MMRD, MUD/MMUD, and Haplo groups, respectively $(\mathrm{P}=0.26)$. In the Cox analysis performed, in both univariate and multivariate analysis, $\mathrm{OS}$ and GFRFS were not significantly different among the three donor type groups (table 6). Adjusted multivariable modeling of OS based on the variables selected in unadjusted unviariable models (the above-mentioned scenario in the methods section) showed that hazard of death in patients who received HSCT from MUD/MMUD was about 3.6 times more than the hazard of death in patients who received HSCT from the haploidentical donors, and this was statistically significant $(P=0.05)$. Moreover, in those who received HSCT from MRD/MMRD, the hazard of death was 12 percent higher than those who received HSCT from haploidentical donors [HR=1.12, (95\% $\mathrm{Cl} 0.34-3.67), \mathrm{P}=0.84$ ].

The 3-years NRM in all patients was 7.84\% (95\% Cl 4.36-12.62). Patients who had undergone MUD/MMUD HSCT showed statistically higher NRM compared to patients undergoing Haplo and MRD/MMRD transplant (table 3): $21.40 \%$ (95\% $\mathrm{Cl} 8.36-38.36)$ versus $10.61 \%$ (95\% $\mathrm{Cl} 3.21-23.14$ ) versus $3.06 \%(95 \% \mathrm{Cl} 0.81-8.01)$, respectively $(P=0.003)$.

Considering the causes of NRM, among patients who died in disease remission in the MUD/MMUD group, we observed six cases of infection and one case of heart failure. In the Haplo group, one patient dying from NRM had aGvHD and four others had infection. In the MRD/MMRD group one case experienced death due to aGvHD, three cases owing to infection and one case because of unknown reason.

Adjusted multivariable modeling of NRM showed that hazard of death in patients who received HSCT from MUD/MMUD was 6 times more than the hazard of death in patients who received HSCT from the haploidentical donors, and this was statistically significant $(P=0.002)$. In those who received HSCT from MRD/MMRD, the hazard of death was not statistically significant higher than those who received HSCT from haploidentical donors $(P=0.23)$.

Although the pre-HSCT estimated risk of CMV reactivation was high in most of the patients, CMV reactivation after HSCT occurred in a total of 61 (33.9\%) of patients. CMV reactivation after HSCT occurred significantly more often in the Haplo and MUD/MMUD group compared with the MRD/MMRD group ( $55.6 \%$ and $43.3 \%$ versus $21.9 \%$, respectively, $P=0.001)$. It is worth knowing that post HSCT CMV reactivation decreased $O S$ and GFRFS in all three groups but it was not statistically significant $(P=0.09)$.

Hemorrhagic cystitis (HC) was another documented complication post-HSCT which occurred in 36 (20\%) patients, and it involved mostly the patients in the Haplo and MUD/MMUD group compared with the MRD/MMRD group (35.6\% and $33.3 \%$ versus $9.5 \%$, respectively, $P=0.000$ ). Sinusoidal obstruction syndrome (SOS) only happened in 5 patients, one from the Haplo group, two from MUD/MMUD and two from the MRD/MMRD group. 


\section{Discussion}

Allogeneic HSCT has augmented the potential of cure in patients with acute leukemia. ${ }^{8}$ Although HLAcompatible related and unrelated donors have been traditionally used for treating acute leukemia patients in need of an allograft, there is a significant proportion of patients for whom it is not possible to identify an HLA-identical acceptable donor. For these patients the use of a haploidentical donor together with alloreactive T-cell elimination by Pt-Cy is the most widely adopted strategy. ${ }^{9}$ Our study showed that for children, adolescent and young adults (CAYA) affected by acute leukemia, in terms of NRM and survival rates, haploidentical HSCT followed by Pt-Cy can offer a better and more accessible chance of cure compared with HSCT from unrelated donors who are hardly reachable especially in the COVID-19 pandemic era .

Different studies have reported that haploidentical HSCT could have similar results to those of MUD and MMUD. ${ }^{10}$ Several reports have even shown comparable outcomes between Haplo and historical MRD, MUD, and MMUD series. ${ }^{11}$ In our study, in consistent with most studies, the MRD/MMRD group had the best survival rates between three donor types, nevertheless, surprisingly, survival rates were higher in the Haplo group compared to MUD/MMUD group.

Saglio et al. using a TBI-based conditioning regimen have reported similar OS rates for Haplo and MUD/MMUD in CAYA patients. ${ }^{12}$ In our study, OS rates were much higher in the Haplo group compared to the MUD/MMUD group. Likewise, in our patients who had undergone haploidentical HSCT, GFRFS was higher and NRM was much lower than the results attained after HSCT from MUD/MMUD.

In terms of GvHD, it has been emphasized that Pt-Cy is able to significantly eliminate the alloreactive Tcells and so reduce the incidence of GvHD, especially in its acute form. ${ }^{13}$ In addition, ATG has been observed to reduce the rate of severe acute and chronic GvHD in the case of matched or mismatched, unrelated allogeneic HSCT. ${ }^{14}$ Chronic GvHD is the leading cause of late illness and death after allogeneic HSCT and one of the risk factors for its development is the use of PB stem cells as a graft source, since Tcell levels in grafts are higher than those in the marrow. ${ }^{15}$ The low incidence of GvHD, particularly chronic GvHD, in our patients compared to other reports in the literature, despite implementation of a MAC regimen together with using $\mathrm{PB}$ as graft source, could be attributed to including high dose of ATG in the conditioning regimen for patients undergoing Haplo and MUD/MMUD HSCT. In our study, the rate of acute and chronic GvHD were even lower in the Haplo group compared with the patients in the MUD/MMUD group. This is accredited to dual in-vivo T-cell depletion caused by ATG and Pt-Cy in the Haplo group. However, adopting a highly effective GvHD prophylaxis, may potentially lead in to increased risk of relapse. This was true in our study, as we had the highest RI in the Haplo group. However, it should be noted that the difference in RI among our three donor types was not statistically significant. It is designated that the HLA disparity could be considered as a contributing factor to allo-reactivity and GvL. ${ }^{16}$ In the matched donor transplant setting, the frequency of donor T-cell precursors directed against leukemia-specific antigens that mediate GvL may be more limited. ${ }^{17}$ Other studies who have 
implemented less rigorous GvHD prophylaxis strategies compared to us, have reported similar RI in Haplo and MUD/MMUD HSCT. ${ }^{18}$

In consideration of transplant toxicity, our data confirm that patients undergoing Haplo HSCT have much lower NRM rates compared to patients undergoing MUD/MMUD HSCT, and the rate of complications such as $\mathrm{HC}$ and SOS seem to be comparable between the two groups. Previous studies comparing NRM rates in Haplo (with Pt-Cy) with MRD and MUD transplants (with standard GvHD prophylaxis) have reported inconsistent results. Whereas some studies reported a higher rate of NRM in Haplo HSCT. ${ }^{19}$

This study was limited by its retrospective design, the inability to adjust for unknown factors, the heterogeneity in conditioning regimens and supportive therapy that may have affected the study outcomes.

\section{Conclusions}

Our study shows that incorporation of ATG in the myeloablative conditioning regimen before transplantation of PB stem cells from MUD/MMUD and Haplo donors reduces the rate of chronic GvHD and graft failure, concomitantly. The rates of OS and GFRFS were higher in the Haplo group compared to MUD/MMUD, hence, our data supports that haploidentical PB- derived HSCT is a practical and valuable clinical option that offers CAYA patients with acute leukemia needing HSCT and lacking matched available donors, a reasonable opportunity for disease control. However, further progress is needed to decrease relapse rate in these patients.

\section{Abbreviations}

ALL: Acute lymphoblastic leukemia

CAYA: Children, Adolescents and young adults

CR: Complete remission

GFRFS: GvHD-free, relapse-free survival rates

GvHD: Graft-versus-host disease

Haplo: haploidentical HSCT

HLA: Human leukocyte antigen

HSCT: hematopoietic stem cell transplantation

MRD: Matched related donors

MUD: Matched unrelated donors 
NRM: Non-relapse mortality

OS: Overall survival

PB: Peripheral blood

Pt-Cy: Posttransplant cyclophosphamide

RFS: Relapse-free survival

\section{Declarations}

- Ethical Approval and Consent to participate: The study was approved by the Committee on Medical Ethics of Tehran University of Medical Sciences (TUMS) and informed consent was obtained from patients or their legal guardians.

- Authors provide consent for publication.

- The data and material is available if needed.

- No funding support for the study is declared.

- Competing Interests

None of the authors have any relevant conflict of interest to disclaim about the present article.

\section{- Authors' contributions}

TR designed and coordinated the study and managed the patients. AK, MR and NA participated the management of patients. AK carried out the statistical analysis. SA conceived of the study. All authors read and approved the final manuscript.

\section{- Acknowledgements}

We would like to thank Ashraf Sadat Hoseini and other nursing staff for their undeniable assistance in caring for our patients.

\section{References}

1 Solomon SR, Sizemore CA, Sanacore M, et al. Total body irradiation-based myeloablative haploidentical stem cell transplantation is a safe and effective alternative to unrelated donor transplantation in patients without matched sibling donors. Biol Blood Marrow Transplant. 2015;21:12991307.

2 Friebert SE, Shepardson LB, Shurin SB, Rosenthal GE, Rosenthal NS. Pediatric bone marrow cellularity: are we expecting too much? J Pediatr Hematol Oncol. 1998;20:439-443. 
Muschler GF, Nitto H, Boehm CA, Easley KA. Age- and gender-related changes in the cellularity of human bone marrow and the prevalence of osteoblastic progenitors. J Orthop Res. 2001;19:117-125

3 Raiola AM, Dominietto A, di Grazia C, et al. Unmanipulated haploidentical transplants compared with other alternative donors and matched sibling grafts. Biol Blood Marrow Transplant. 2014;20:1573-9.

Bashey A, Zhang X, Sizemore CA, et al. T-cell-replete HLA-haploidentical hematopoietic transplantation for hematologic malignancies using posttransplantation cyclophosphamide results in outcomes equivalent of contemporaneous HLA-matched related or unrelated donor transplantation. J Clin Oncol. 2013;31:1310-6.

Di Stasi A, Milton DR, Poon LM, et al. Similar transplantation outcomes for acute myeloid leukemia and myelodysplastic syndrome patients with haploidentical versus 10/10 human leukocyte antigen-matched unrelated and related donors. Biol Blood Marrow Transplant. 2014;20:1975-81.

4 George B, Pati N, Gilroy N, Ratnamohan M, Huang G, Kerridge I, Hertzberg M, Gottlieb D, Bradstock K. Pre-transplant cytomegalovirus (CMV) serostatus remains the most important determinant of CMV reactivation after allogeneic hematopoietic stem cell transplantation in the era of surveillance and preemptive therapy. Transpl Infect Dis. 2010 Aug 1;12(4):322-9. doi: 10.1111/j.1399-3062.2010.00504.x. Epub 2010 May 11. PMID: 20487414.

5 Ruggeri, A., Labopin, M., Ciceri, F. et al. Definition of GvHD-free, relapse-free survival for registrybased studies: an ALWP-EBMT analysis on patients with AML in remission. Bone Marrow Transplant 51, 610-611 (2016). https://doi.org/10.1038/bmt.2015.305)

6 Thiede C, Florek M, Bornhäuser M, Ritter M, Mohr B, Brendel C, et al. Rapid quantification of mixed chimerism using multiplex amplification of short tandem repeat markers and fluorescence detection. Bone Marrow Transpl. 1999;23:1055-60.

7 Armand P, Kim HT, Logan BR, Wang Z, Alyea EP, Kalaycio ME, et al. Validation and refinement of the disease risk index for allogeneic stem cell transplantation. Blood. 2014;123:3664-71.

Glucksberg H, Storb R, Fefer A, Buckner CD, Neiman PE, Clift RA, et al. Clinical manifestations of graftversus-host disease in human recipients of marrow from HL-A-matched sibling donors. Transplantation. 1974;18:295-304.

8 Afify Z, Hunt L, Green A, Guttridge M, Cornish J, Oakhill A. Factors affecting the outcome of stem cell transplantation from unrelated donors for childhood acute lymphoblastic leukemia in third remission. Bone Marrow Transpl. 2005;35:1041-7.

Balduzzi A, Valsecchi MG, Uderzo C, De Lorenzo P, Klingebiel T, Peters C, et al. Chemotherapy versus allogeneic transplantation for very-high-risk childhood acute lymphoblastic leukaemia in first complete 
remission: comparison by genetic randomisation in an international prospective study. Lancet. 2005;366:635-42.

Cornish J, Oakhill A. The management of relapsed acute lymphoblastic leukaemia. Bone Marrow Transpl. 2001;28(Suppl 1):S9.

Klingebiel T, Cornish J, Labopin M, Locatelli F, Darbyshire P, Handgretinger R, et al. Results and factors influencing outcome after fully haploidentical hematopoietic stem cell transplantation in children with very high-risk acute lymphoblastic leukemia: impact of center size: an analysis on behalf of the Acute Leukemia and Pediatric Disease Working Parties of the European Blood and Marrow Transplant group. Blood. 2010;115:3437-46.

9 Nagler A, Ruggeri A. Haploidentical stem cell transplantation (HaploSCT) for patients with acute leukemia-an update on behalf of the ALWP of the EBMT. Bone Marrow Transpl.2019;54:713-8.

10 Piemontese S, Ciceri F, Labopin M, Arcese W, Kyrcz-Krzemien S, Santarone S, et al. A comparison between allogeneic stem cell transplantation from unmanipulated haploidentical and unrelated donors in acute leukemia. J Hematol Oncol. 2017;10. https://www. ncbi.nlm.nih.gov/pmc/articles/PMC5248464/.

Sun Y, Beohou E, Labopin M, Volin L, Milpied N, Yakoub-Agha I, et al. Unmanipulated haploidentical versus matched unrelated donor allogeneic stem cell transplantation in adult patients with acute myelogenous leukemia in first remission: a retrospective pair-matched comparative study of the Beijing approach with the EBMT database. Haematologica. 2016;101:e352-4.

Lorentino F, Labopin M, Bernardi M, Ciceri F, Socié G, Cornelissen JJ, et al. Comparable outcomes of haploidentical, 10/10 and 9/10unrelated donor transplantation in adverse karyotype AML in first complete remission. Am J Hematol. 2018;93:1236-44.

11 Raiola AM, Dominietto A, di Grazia C, et al. Unmanipulated haploidentical transplants compared with other alternative donors and matched sibling grafts. Biol Blood Marrow Transplant. 2014;20:1573-9.

Bashey A, Zhang X, Sizemore CA, et al. T-cell-replete HLA-haploidentical hematopoietic transplantation for hematologic malignancies using posttransplantation cyclophosphamide results in outcomes equivalent of contemporaneous HLA-matched related or unrelated donor transplantation. J Clin Oncol. 2013;31:1310-6.

Di Stasi A, Milton DR, Poon LM, et al. Similar transplantation outcomes for acute myeloid leukemia and myelodysplastic syndrome patients with haploidentical versus 10/10 human leukocyte antigen-matched unrelated and related donors. Biol Blood Marrow Transplant. 2014;20:1975-81.

Luo Y, Xiao H, Lai X, et al. T-cell-replete haploidentical HSCT with low-dose anti-T-lymphocyte globulin compared with matched sibling HSCT and unrelated HSCT. Blood. 2015;124:2735-43. 
12 Saglio F, Berger M, Spadea M, Pessolano R, Carraro F, Barone M, Quarello P, Vassallo E, Fagioli F. Haploidentical HSCT with post transplantation cyclophosphamide versus unrelated donor HSCT in pediatric patients affected by acute leukemia. Bone Marrow Transplantation. 2021 Mar;56(3):586-95.

13 Wachsmuth LP, Patterson MT, Eckhaus MA, Venzon DJ, Gress RE, Kanakry CG.

Posttransplantation cyclophosphamide prevents graft-versus-host disease by inducing alloreactive $\mathrm{T}$ cell dysfunction and suppression. J Clin Invest. 2019;129:2357-73

14 Finke J, Bethge WA, Schmoor C, et al. Standard graft-versus-host disease prophylaxis with or without anti-T-cell globulin in haematopoietic cell transplantation from matched unrelated donors: a randomised, open-label, multicentre phase 3 trial. Lancet Oncol 2009;10:855-864.

Bacigalupo A, Lamparelli T, Bruzzi P, et al. Antithymocyte globulin for graft-versus-host disease prophylaxis in transplants from unrelated donors: 2 randomized studies from Gruppo Italiano Trapianti Midollo Osseo (GITMO). Blood 2001;98:2942-2947

15 Wingard JR, Majhail NS, Brazauskas R, et al. Long-term survival and late deaths after allogeneic hematopoietic cell transplantation. J Clin Oncol 2011;29:2230-2239.

Martin PJ, Counts GW Jr, Appelbaum FR, et al. Life expectancy in patients surviving more than 5 years after hematopoietic cell transplantation. J Clin Oncol 2010;28:1011-1016.

Arai S, Arora M, Wang T, et al. Increasing incidence of chronic graft-versus-host disease in allogeneic transplantation: a report from the Center for International Blood and Marrow Transplant Research. Biol Blood Marrow Transplant 2015;21:266-274.

16 Shimoni A, Labopin M, Finke J, Ciceri F, Deconinck E, Kröger N, Gramatzki M, Stelljes M, Blaise D, Stoelzel F, Chevallier P. Donor selection for a second allogeneic stem cell transplantation in AML patients relapsing after a first transplant: a study of the Acute Leukemia Working Party of EBMT. Blood cancer journal. 2019 Nov 18;9(12):1-9.

17 Distler, E. et al. Alloreactive and leukemia-reactive $T$ cells are preferentially derived from naive precursors in healthy donors: implications for immunotherapy with memory T cells. Haematologica 96, 1024-1032 (2011).

18 Bertaina A, Zecca M, Buldini B, Sacchi N, Algeri M, Saglio F, et al. Unrelated donor vs HLAhaploidentical $\alpha / \beta$ T-cell- and Bcell-depleted HSCT in children with acute leukemia. Blood. 2018;132:2594-607.

Saglio F, Berger M, Spadea M, Pessolano R, Carraro F, Barone M, Quarello P, Vassallo E, Fagioli F. Haploidentical HSCT with post transplantation cyclophosphamide versus unrelated donor HSCT in pediatric patients affected by acute leukemia. Bone Marrow Transplantation. 2021 Mar;56(3):586-95. 
19 Versluis J, Labopin M, Ruggeri A, et al. Alternative donors for allogeneic hematopoietic stem cell transplantation in poor-risk AML in CR1. Blood Adv. 2017;1(7):477-85.

Piemontese S, Ciceri F, Labopin M, et al. A comparison between allogeneic stem cell transplantation from unmanipulated haploidentical and unrelated donors in acute leukemia. J Hematol Oncol. 2017;10(1):24.

Baron F, Labopin M, Ruggeri A, et al. Impact of donor type in patients with AML given allogeneic hematopoietic cell transplantation after low-dose TBI based regimen. Clin Cancer Res. 2018;24(12):clincanres.3622.2017.

Rashidi A, Hamadani M, Zhang M-J, et al. Outcomes of haploidentical vs matched sibling transplantation for acute myeloid leukemia in first complete remission. Blood Adv. 2019;3(12):1826-36.

\section{Tables}

Table 1 Patients and transplantation characteristics

\begin{tabular}{|c|c|c|c|c|c|c|}
\hline & & Total $(n=180)$ & $\begin{array}{l}\text { Haplo } \\
(n=45)\end{array}$ & $\begin{array}{l}\text { MUD/MMUD } \\
(\mathrm{n}=30)\end{array}$ & $\begin{array}{l}\text { MRD/MMRD } \\
(\mathrm{n}=105)\end{array}$ & P-value \\
\hline Gender & Female & $60(33.3 \%)$ & $12(26.7 \%)$ & $10(33.3 \%)$ & $38(36.2 \%)$ & 0.526 \\
\hline \multirow[t]{2}{*}{ Leukemia type } & B-ALL & $96(53.3 \%)$ & $20(44.4 \%)$ & $23(76.7 \%)$ & $53(50.5 \%)$ & \multirow[t]{2}{*}{0.070} \\
\hline & T-ALL & $22(12.2 \%)$ & $7(15.6 \%)$ & $1(3.3 \%)$ & $14(13.3 \%)$ & \\
\hline \multirow[t]{3}{*}{ WBC at diagnosis $\left(\times 10^{9} / 1\right)$} & $\leq 50$ & $69(59.0 \%)$ & $18(62.1 \%)$ & $14(58.3 \%)$ & $37(57.8 \%)$ & \multirow[t]{3}{*}{0.984} \\
\hline & $50-100$ & $19(16.2 \%)$ & $5(17.2 \%)$ & $4(16.7 \%)$ & $10(15.6 \%)$ & \\
\hline & $>100$ & $29(24.8 \%)$ & $6(20.7 \%)$ & $6(25.0 \%)$ & $17(54.7 \%)$ & \\
\hline \multirow[t]{2}{*}{ Disease status at HSCT } & CR1 & $93(51.7 \%)$ & $17(37.8 \%)$ & $11(36.7 \%)$ & $65(61.9 \%)$ & \multirow[t]{2}{*}{0.021} \\
\hline & CR2 & $67(37.2 \%)$ & $23(51.1 \%)$ & $15(50.0 \%)$ & $29(27.6 \%)$ & \\
\hline \multirow{2}{*}{ Relapse site } & $\mathrm{BM} / \mathrm{BM}+$ & $62(34.4 \%)$ & $22(48.9 \%)$ & $14(46.7 \%)$ & $26(24.8 \%)$ & \multirow{2}{*}{0.084} \\
\hline & Extramedullary & $24(13.3 \%)$ & $5(11.1 \%)$ & $5(16.7 \%)$ & $14(13.3 \%)$ & \\
\hline \multirow[t]{2}{*}{ Age at HSCT (year) } & $\leq 15$ & $123(68.3 \%)$ & $26(57.8 \%)$ & $23(76.7 \%)$ & $74(70.5 \%)$ & \multirow[t]{2}{*}{0.174} \\
\hline & $>15$ & $57(31.7 \%)$ & $19(42.2 \%)$ & $7(23.3 \%)$ & $31(29.5 \%)$ & \\
\hline \multirow[t]{3}{*}{ R/D blood group matching } & Matched & $113(62.8 \%)$ & $36(80 \%)$ & $9(30 \%)$ & $68(64.8 \%)$ & \multirow[t]{3}{*}{0.001} \\
\hline & Major MM & $42(23.3 \%)$ & $4(8.9 \%)$ & $11(36.7 \%)$ & 27 (25.7\%) & \\
\hline & Minor MM & $25(13.9 \%)$ & $5(11.1 \%)$ & $10(33.3 \%)$ & $10(9.5 \%)$ & \\
\hline \multirow[t]{2}{*}{ Donor age (year) } & $\leq 30$ & $128(71.5 \%)$ & $22(50 \%)$ & $13(43.3 \%)$ & $93(88.6 \%)$ & \multirow[t]{2}{*}{0.001} \\
\hline & $>30$ & $51(28.5 \%)$ & $22(50 \%)$ & 17 (56.7\%) & $12(11.4 \%)$ & \\
\hline
\end{tabular}

ALL: acute lymphoblastic leukemia, AML: acute myeloblastic leukemia, BM: bone marrow, BM+: involvement of bone marrow together with other sites, CR: complete remission, Haplo: HLA-haploidentical donors, MM: mismatched, MRD/MMRD: HLAmatched related and HLA-mismatched related donors, MUD/MMUD: HLA-matched unrelated and HLA-mismatched unrelated donors, R/D: recipient/donor, WBC: white blood cell. 
Table 2 Comparison of engraftment and GVHD in different donor types.

\begin{tabular}{|c|c|c|c|c|c|c|}
\hline & & Total & Haplo & MUD/MMUD & MRD/MMRD & $\begin{array}{l}\mathrm{P}- \\
\text { value }\end{array}$ \\
\hline \multirow[t]{2}{*}{$\begin{array}{l}\text { Neutrophil } \\
\text { recovery }\end{array}$} & Mean duration (95\% CI) & $\begin{array}{l}11.34(11.10- \\
11.58)\end{array}$ & $\begin{array}{l}12.20(11.76- \\
12.64)\end{array}$ & $\begin{array}{l}12.17(11.71- \\
12.63)\end{array}$ & $\begin{array}{l}10.73(10.43- \\
11.03)\end{array}$ & \multirow[t]{2}{*}{0.000} \\
\hline & $\mathrm{N}(\%)$ & $180(100 \%)$ & $45(100 \%)$ & $30(100 \%)$ & 105 (100\%) & \\
\hline \multirow[t]{2}{*}{ Platelet recovery } & Mean duration $(95 \% \mathrm{CI})$ & $\begin{array}{l}14.70(12.64- \\
16.76)\end{array}$ & $\begin{array}{l}14.67(11.89- \\
17.45)\end{array}$ & $\begin{array}{l}16.21(10.99- \\
21.42)\end{array}$ & $\begin{array}{l}14.30(11.31- \\
17.30)\end{array}$ & \multirow[t]{2}{*}{0.809} \\
\hline & $\mathrm{N}(\%)$ & $176(97.7 \%)$ & $42(93.3 \%)$ & $29(96.6 \%)$ & $105(100 \%)$ & \\
\hline \multirow[t]{2}{*}{$\begin{array}{l}\text { Grade II-IV acute } \\
\text { GvHD }\end{array}$} & $\begin{array}{l}\text { Cumulative incidence at day } \\
100 \text { (SE) }\end{array}$ & $23.8 \%(4.5)$ & $10.5 \%(7.0)$ & $31.6 \%(11.8)$ & $27.3 \%(6.0)$ & 0.845 \\
\hline & N (\%) & 70 (38.9\%) & $17(37.8 \%)$ & $13(43.3 \%)$ & $40(38.1 \%)$ & 0.860 \\
\hline \multirow[t]{2}{*}{ Chronic GvHD } & $\begin{array}{l}\text { Cumulative incidence at } 3 \\
\text { years (SE) }\end{array}$ & $20.3 \%(3.9)$ & $7.0 \%(5.0)$ & $22.5 \%(10.3)$ & $23.3(4.9)$ & 0.105 \\
\hline & $\mathrm{N}(\%)$ & $27(15 \%)$ & $2(4.4 \%)$ & $4(13.3 \%)$ & $21(20 \%)$ & 0.048 \\
\hline
\end{tabular}

GvHD: graft versus host disease, Haplo: HLA-haploidentical donors, MM: mismatched, MRD/MMRD: HLA-matched related and HLA-mismatched related donors, MUD/MMUD: HLA-matched unrelated and HLA-mismatched unrelated donors.

Table 3 One and three-year RI and NRM. 


\begin{tabular}{|c|c|c|c|c|c|c|}
\hline & & 1-year RI (95\% CI) & 3-year RI (95\% CI) & $\begin{array}{l}P \text { - } \\
\text { value }\end{array}$ & $\begin{array}{l}1 \text { and 3-year NRM \% } \\
(95 \% \mathrm{CI})\end{array}$ & $\begin{array}{l}P \text { - } \\
\text { value }\end{array}$ \\
\hline \multirow[t]{3}{*}{ Leukemia type } & B-ALL & $\begin{array}{l}22.78 \%(14.57- \\
32.12)\end{array}$ & $\begin{array}{l}34.87 \%(23.89- \\
46.05)\end{array}$ & \multirow[t]{3}{*}{0.902} & $10.24 \%(4.96-17.75)$ & \multirow[t]{3}{*}{0.497} \\
\hline & T-ALL & $\begin{array}{l}43.60 \%(21.45- \\
63.92)\end{array}$ & $\begin{array}{l}53.86 \%(24.62- \\
76.09)\end{array}$ & & $5.12 \%(0.30-21.80)$ & \\
\hline & AML & $\begin{array}{l}8.70 \%(3.15- \\
17.81)\end{array}$ & $\begin{array}{l}25.22 \%(13.55- \\
38.71)\end{array}$ & & $5.05 \%(1.30-12.80)$ & \\
\hline \multirow[t]{3}{*}{$\begin{array}{l}\text { WBC at diagnosis }(\times \\
\left.10^{9} / 1\right)\end{array}$} & $\leq 50$ & $\begin{array}{l}16.74 \%(8.44- \\
27.46)\end{array}$ & $\begin{array}{l}21.52 \%(11.55- \\
33.52)\end{array}$ & \multirow[t]{3}{*}{0.178} & $7.19 \%(2.22-16.18)$ & \multirow[t]{3}{*}{0.647} \\
\hline & $50-100$ & $\begin{array}{l}24.88 \%(6.94- \\
48.39)\end{array}$ & $\begin{array}{l}35.64 \%(10.58- \\
62.26)\end{array}$ & & $10.52 \%(1.65-29.05)$ & \\
\hline & $>100$ & $\begin{array}{l}32.51 \%(15.86- \\
50.38)\end{array}$ & $\begin{array}{l}40.62 \%(18.89- \\
61.45)\end{array}$ & & $10.69 \%(2.60-25.43)$ & \\
\hline \multirow[t]{3}{*}{ Relapse site } & No relapse & $\begin{array}{l}14.27 \%(7.76- \\
22.69)\end{array}$ & $\begin{array}{l}14.27 \%(7.76- \\
22.69)\end{array}$ & \multirow[t]{3}{*}{0.049} & $6.13 \%(2.24-12.82)$ & \multirow[t]{3}{*}{0.134} \\
\hline & $\mathrm{BM} / \mathrm{BM}+$ & $\begin{array}{l}20.13 \%(10.17- \\
32.49)\end{array}$ & $\begin{array}{l}20.13 \%(10.17- \\
32.49)\end{array}$ & & $14.0 \%(5.99-25.31)$ & \\
\hline & Extramedullary & $\begin{array}{l}\text { 44.71\% (21.73- } \\
65.42)\end{array}$ & $\begin{array}{l}44.71 \%(21.73- \\
65.42)\end{array}$ & & $4.82 \%(0.29-20.59)$ & \\
\hline \multirow[t]{3}{*}{$\begin{array}{l}\text { Disease status at } \\
\text { HSCT }\end{array}$} & CR1 & $\begin{array}{l}14.44 \%(7.85- \\
22.95)\end{array}$ & $\begin{array}{l}29.70 \%(19.09- \\
41.07)\end{array}$ & \multirow[t]{3}{*}{0.122} & $4.88 \%(1.57-11.14)$ & \multirow[t]{3}{*}{0.181} \\
\hline & CR2 & $\begin{array}{l}30.14 \%(19.15- \\
41.88)\end{array}$ & $\begin{array}{l}40.24 \%(26.67- \\
53.43)\end{array}$ & & $12.94 \%(5.92-29.72)$ & \\
\hline & $\mathrm{CR} \geq 3$ & $\begin{array}{l}15.31 \%(3.59- \\
34.68)\end{array}$ & $\begin{array}{l}29.80 \%(9.78- \\
53.22)\end{array}$ & & $5.0 \%(0.31-21.10)$ & \\
\hline \multirow[t]{2}{*}{ Gender } & Male & $\begin{array}{l}25.42 \%(17.62- \\
33.94) \\
\end{array}$ & $\begin{array}{l}39.47 \%(28.88- \\
49.47)\end{array}$ & \multirow[t]{2}{*}{0.035} & $6.39 \%(2.79-12.08)$ & \multirow[t]{2}{*}{0.318} \\
\hline & Female & $\begin{array}{l}10.73 \%(4.31- \\
20.51)\end{array}$ & $\begin{array}{l}23.63 \%(12.26- \\
37.10)\end{array}$ & & $10.68 \%(4.25-20.50)$ & \\
\hline \multirow[t]{2}{*}{$\begin{array}{l}\text { Age at HSCT } \\
\text { (year) }\end{array}$} & $\leq 15$ & $\begin{array}{l}21.36 \%(14.40- \\
29.25)\end{array}$ & $\begin{array}{l}34.73 \%(25.31- \\
44.31)\end{array}$ & \multirow[t]{2}{*}{0.582} & $4.31 \%(1.59-9.20)$ & \multirow[t]{2}{*}{0.01} \\
\hline & $>15$ & $\begin{array}{l}18.44 \%(8.96- \\
30.58)\end{array}$ & $\begin{array}{l}32.32 \%(17.37- \\
48.25)\end{array}$ & & $16.48 \%(7.53-28.45)$ & \\
\hline \multirow[t]{3}{*}{ Donor type } & Haplo & $\begin{array}{l}25.82 \%(12.12- \\
41.94)\end{array}$ & $\begin{array}{l}40.95 \%(18.41- \\
62.44)\end{array}$ & \multirow[t]{3}{*}{0.902} & $10.61 \%(3.21-23.14)$ & \multirow[t]{3}{*}{0.003} \\
\hline & MUD/MMUD & $\begin{array}{l}18.33 \%(6.36- \\
35.18)\end{array}$ & $\begin{array}{l}32.94 \%(11.92- \\
56.01)\end{array}$ & & $21.40 \%(8.36-38.36)$ & \\
\hline & $\mathrm{MRD} / \mathrm{MMRD}$ & $\begin{array}{l}\text { 19.69\% (12.58- } \\
27.98)\end{array}$ & $\begin{array}{l}33.17 \%(23.64- \\
42.99)\end{array}$ & & $3.06 \%(0.81-8.01)$ & \\
\hline \multirow[t]{3}{*}{$\mathrm{R} / \mathrm{D} \mathrm{ABO}$ matching } & Matched & $\begin{array}{l}18.12 \%(11.38- \\
26.11)\end{array}$ & $\begin{array}{l}35.81 \%(25.24- \\
46.49)\end{array}$ & \multirow[t]{3}{*}{0.979} & $5.65 \%(2.29-11.24)$ & \multirow[t]{3}{*}{0.427} \\
\hline & Major MM & $\begin{array}{l}22.51 \%(10.95- \\
36.59)\end{array}$ & $\begin{array}{l}29.43 \%(15.42- \\
44.93)\end{array}$ & & $10.13 \%(3.13-21.98)$ & \\
\hline & Minor MM & $\begin{array}{l}26.76 \%(10.50- \\
46.25)\end{array}$ & $\begin{array}{l}32.73 \%(13.76- \\
53.31)\end{array}$ & & $13.58 \%(3.16-31.52)$ & \\
\hline \multirow[t]{2}{*}{ Donor age (year) } & $\leq 30$ & $\begin{array}{l}\text { 19.44\% (12.84- } \\
27.07)\end{array}$ & $\begin{array}{l}32.87 \%(23.64- \\
42.38)\end{array}$ & \multirow[t]{2}{*}{0.812} & $6.65 \%(3.08-12.12)$ & \multirow[t]{2}{*}{0.475} \\
\hline & $>30$ & $\begin{array}{l}23.04 \%(12.12- \\
36.01)\end{array}$ & $\begin{array}{l}36.10 \%(20.91- \\
51.51)\end{array}$ & & $10.48 \%(3.77-21.16)$ & \\
\hline $\begin{array}{l}\text { CD34 }^{+} \text {Cell dose } \\
\text { infused }\end{array}$ & $\leq 6$ & $\begin{array}{l}23.21 \%(15.94- \\
31.29)\end{array}$ & $\begin{array}{l}34.39 \%(25.28- \\
43.66)\end{array}$ & 0.318 & $6.84 \%(3.17-12.42)$ & 0.137 \\
\hline
\end{tabular}




\begin{tabular}{|c|c|c|c|c|c|c|}
\hline \multirow[t]{2}{*}{$\left(\times 10^{6} / \mathrm{kg}\right)$} & $6-8$ & $\begin{array}{l}9.01 \%(2.23- \\
21.81)\end{array}$ & $\begin{array}{l}27.66 \%(9.81- \\
49.09)\end{array}$ & & $16.38 \%(5.55-32.24)$ & \\
\hline & $>8$ & $\begin{array}{l}25.22 \%(7.29- \\
48.45)\end{array}$ & $\begin{array}{l}53.26 \%(13.96- \\
81.75)\end{array}$ & & 0 & \\
\hline \multirow{2}{*}{$\begin{array}{l}\mathrm{CD}^{+} \text {Cell dose } \\
\text { infused } \\
\left(\times 10^{6} / \mathrm{kg}\right)\end{array}$} & $\leq 250$ & $\begin{array}{l}18.73 \%(10-78- \\
28.39)\end{array}$ & $\begin{array}{l}36.02 \%(23.13- \\
49.06)\end{array}$ & \multirow[t]{2}{*}{0.923} & $9.57 \%(4.14-17.75)$ & \multirow[t]{2}{*}{0.471} \\
\hline & $>250$ & $\begin{array}{l}22.31 \%(14.24- \\
31.51)\end{array}$ & $\begin{array}{l}33.44 \%(22.99- \\
44.21)\end{array}$ & & $6.60 \%(2.67-13.01)$ & \\
\hline
\end{tabular}

ALL: acute lymphoblastic leukemia, AML: acute myeloblastic leukemia, BM: bone marrow, BM+: involvement of bone marrow together with other sites, CR: complete remission, Haplo: HLA-haploidentical donors, MM: mismatched, MRD/MMRD: HLAmatched related and HLA-mismatched related donors, MUDMMUD: HLA-matched unrelated and HLA-mismatched unrelated donors, NRM: non-relapse mortality, R/D: recipient/donor, RI: relapse incidence, WBC: white blood cell.

Table 4 One and three-year OS and GFRFS. 


\begin{tabular}{|c|c|c|c|c|c|c|c|}
\hline & & $\begin{array}{l}\text { 1-year OS } \\
(95 \% \text { CI })\end{array}$ & $\begin{array}{l}\text { 3-year OS (95\% } \\
\text { CI) }\end{array}$ & $\begin{array}{l}P- \\
\text { value }\end{array}$ & $\begin{array}{l}\text { 1-year GFRFS } \\
(95 \% \mathrm{CI})\end{array}$ & $\begin{array}{l}\text { 3-year GFRFS } \\
(95 \% \mathrm{CI})\end{array}$ & $\begin{array}{l}P- \\
\text { value }\end{array}$ \\
\hline \multirow[t]{3}{*}{ Leukemia type } & B-ALL & $\begin{array}{l}74.22 \% \text { (63.38- } \\
82.29)\end{array}$ & $\begin{array}{l}63.49(51.0- \\
73.61)\end{array}$ & \multirow[t]{3}{*}{0.002} & $\begin{array}{l}53.6 \%(42.32- \\
63.62)\end{array}$ & $\begin{array}{l}39.35 \% 27.77- \\
50.71)\end{array}$ & \multirow[t]{3}{*}{0.032} \\
\hline & T-ALL & $\begin{array}{l}59.48 \% \text { (34.69- } \\
77.50)\end{array}$ & $\begin{array}{l}47.59 \%(20.04- \\
70.96)\end{array}$ & & $\begin{array}{l}47.03 \% \\
(24.92-66.40)\end{array}$ & $\begin{array}{l}35.27 \%(12.26- \\
59.61)\end{array}$ & \\
\hline & AML & $\begin{array}{l}91.51 \%(80.76- \\
96.38)\end{array}$ & $\begin{array}{l}83.11 \%(68.06- \\
91.49)\end{array}$ & & $\begin{array}{l}73.55 \% \\
(59.91-83.18)\end{array}$ & $\begin{array}{l}55.0 \%(39.83- \\
67.82)\end{array}$ & \\
\hline \multirow[t]{3}{*}{$\begin{array}{l}\text { WBC at diagnosis } \\
\left(\times 10^{9} / \mathrm{l}\right)\end{array}$} & $\leq 50$ & $\begin{array}{l}\text { 83.93\% (71.14- } \\
91.38)\end{array}$ & $\begin{array}{l}78.69 \% \text { (64.23- } \\
87.83)\end{array}$ & \multirow[t]{3}{*}{0.145} & $\begin{array}{l}61.78 \% \\
(47.56-73.19)\end{array}$ & $\begin{array}{l}54.07 \%(39.24- \\
66.75)\end{array}$ & \multirow[t]{3}{*}{0.133} \\
\hline & $50-100$ & $\begin{array}{l}\text { 62.64\% (34.15- } \\
81.57)\end{array}$ & $\begin{array}{l}62.64 \%(34.15- \\
81.57)\end{array}$ & & $\begin{array}{l}48.58 \% \\
(22.13-70.78)\end{array}$ & $\begin{array}{l}38.86 \%(14.09- \\
63.39)\end{array}$ & \\
\hline & $>100$ & $\begin{array}{l}70.83 \%(49.88- \\
84.29)\end{array}$ & $\begin{array}{l}70.83 \% \text { (49.88- } \\
84.29)\end{array}$ & & $\begin{array}{l}44.87 \% \\
(25.72-62.31)\end{array}$ & $\begin{array}{l}34.9 \%(14.20- \\
56.68)\end{array}$ & \\
\hline \multirow[t]{3}{*}{ Relapse site } & No relapse & $\begin{array}{l}86.54 \% \text { (76.96- } \\
92.33)\end{array}$ & $\begin{array}{l}79.11 \%(67.20- \\
87.10)\end{array}$ & \multirow[t]{3}{*}{0.010} & $\begin{array}{l}68.47 \% \\
(57.17-77.37)\end{array}$ & $\begin{array}{l}49.39 \%(36.80- \\
60.78)\end{array}$ & \multirow[t]{3}{*}{0.053} \\
\hline & $\mathrm{BM} / \mathrm{BM}+$ & $\begin{array}{l}72.53 \% \text { (58.89- } \\
82.31)\end{array}$ & $\begin{array}{l}57.92 \%(41.74- \\
71.08))\end{array}$ & & $\begin{array}{l}53.15 \% \\
(39.14-65.31)\end{array}$ & $\begin{array}{l}38.24 \%(24.56- \\
51.78)\end{array}$ & \\
\hline & Extramedullary & $\begin{array}{l}61.48 \% \text { (37.17- } \\
78.73)\end{array}$ & $\begin{array}{l}53.80 \%(28.72- \\
73.49)\end{array}$ & & $\begin{array}{l}40.45 \%(20.0- \\
60.11)\end{array}$ & $\begin{array}{l}40.45 \%(20.0- \\
60.11)\end{array}$ & \\
\hline \multirow[t]{3}{*}{$\begin{array}{l}\text { Disease status at } \\
\text { HSCT }\end{array}$} & CR1 & $\begin{array}{l}87.71 \% \text { (78.32- } \\
93.21)\end{array}$ & $\begin{array}{l}80.18 \% \text { (68.25- } \\
88.01)\end{array}$ & \multirow[t]{3}{*}{0.002} & $\begin{array}{l}69.41 \% \\
(58.11-78.23) \\
\end{array}$ & $\begin{array}{l}50.07 \%(37.35- \\
61.51)\end{array}$ & \multirow[t]{3}{*}{0.0358} \\
\hline & CR2 & $\begin{array}{l}65.78 \%(52.22- \\
76.34)\end{array}$ & $\begin{array}{l}54.51 \%(39.23- \\
67.47)\end{array}$ & & $\begin{array}{l}46.39 \% \\
(33.22-58.54)\end{array}$ & $\begin{array}{l}36.57 \% \text { (23.60- } \\
49.61)\end{array}$ & \\
\hline & $\mathrm{CR} \geq 3$ & $\begin{array}{l}77.78 \% \text { (50.52- } \\
91.17)\end{array}$ & $\begin{array}{l}62.85 \%(34.19- \\
81.80)\end{array}$ & & $\begin{array}{l}58.34 \% \\
(33.65-76.59)\end{array}$ & $\begin{array}{l}43.75 \%(19.98- \\
65.42)\end{array}$ & \\
\hline \multirow[t]{2}{*}{ Gender } & Male & $\begin{array}{l}77.74 \% \text { (68.55- } \\
84.54)\end{array}$ & $\begin{array}{l}64.53 \%(53.15- \\
73.81)\end{array}$ & \multirow[t]{2}{*}{0.264} & $\begin{array}{l}54.78 \% \\
(44.79-63.71) \\
\end{array}$ & $\begin{array}{l}39.38 \% \text { (29.02- } \\
49.56)\end{array}$ & \multirow[t]{2}{*}{0.073} \\
\hline & Female & $\begin{array}{l}79.65 \% \text { (66.11- } \\
88.24)\end{array}$ & $\begin{array}{l}\text { 77.0\% (62.71- } \\
86.38)\end{array}$ & & $\begin{array}{l}69.19 \% \\
(55.03-79.68)\end{array}$ & $\begin{array}{l}53.37 \%(37.77- \\
66.71)\end{array}$ & \\
\hline \multirow[t]{2}{*}{$\begin{array}{l}\text { Age at HSCT } \\
\text { (year) }\end{array}$} & $\leq 15$ & $\begin{array}{l}79.85 \% \text { (71.18- } \\
86.17)\end{array}$ & $\begin{array}{l}70.59 \% \text { (60.21- } \\
78.73)\end{array}$ & \multirow[t]{2}{*}{0.447} & $\begin{array}{l}67.04 \% \\
(57.55-74.87)\end{array}$ & $\begin{array}{l}49.87 \% \text { (39.34- } \\
59.51)\end{array}$ & \multirow[t]{2}{*}{0.008} \\
\hline & $>15$ & $\begin{array}{l}74.87 \% \text { (59.71- } \\
85.01)\end{array}$ & $\begin{array}{l}63.96 \%(45.94- \\
77.36)\end{array}$ & & $\begin{array}{l}41.11 \% \\
(26.73-54.94) \\
\end{array}$ & $\begin{array}{l}29.98 \% \text { (15.99- } \\
45.31)\end{array}$ & \\
\hline \multirow[t]{3}{*}{ Donor type } & Haplo & $\begin{array}{l}77.55 \% \text { (59.67- } \\
88.23)\end{array}$ & $\begin{array}{l}64.18 \% \text { (39.76- } \\
80.79)\end{array}$ & \multirow[t]{3}{*}{0.082} & $\begin{array}{l}58.23 \% \\
(39.73-72.84)\end{array}$ & $\begin{array}{l}42.46 \%(20.41- \\
63.01)\end{array}$ & \multirow[t]{3}{*}{0.268} \\
\hline & MUD/MMUD & $\begin{array}{l}63.24 \%(42.01- \\
78.50)\end{array}$ & $\begin{array}{l}54.21 \%(29.61- \\
73.49)\end{array}$ & & $\begin{array}{l}47.06 \% \\
(26.87-64.91) \\
\end{array}$ & $\begin{array}{l}30.89 \%(10.70- \\
53.80)\end{array}$ & \\
\hline & MRD/MMRD & $\begin{array}{l}82.8 \% \text { (73.76- } \\
88.96)\end{array}$ & $\begin{array}{l}73.58 \% \text { (62.98- } \\
81.59)\end{array}$ & & $\begin{array}{l}63.17 \% \\
(52.90-71.80) \\
\end{array}$ & $\begin{array}{l}47.11 \%(36.48- \\
57.02)\end{array}$ & \\
\hline \multirow[t]{3}{*}{$\mathrm{R} / \mathrm{D} \mathrm{ABO}$ matching } & Matched & $\begin{array}{l}84.07 \% \text { (75.20- } \\
89.98)\end{array}$ & $\begin{array}{l}74.40 \% \text { (63.09- } \\
82.71)\end{array}$ & \multirow[t]{3}{*}{0.080} & $\begin{array}{l}65.33 \% \\
(55.22-73.69) \\
\end{array}$ & $\begin{array}{l}47.96 \% \text { (36.76- } \\
58.31)\end{array}$ & \multirow[t]{3}{*}{0.364} \\
\hline & Major MM & $\begin{array}{l}72.50 \% \text { (55.76- } \\
83.77)\end{array}$ & $\begin{array}{l}62.19 \%(44.04- \\
75.96)\end{array}$ & & $\begin{array}{l}53.47 \% \\
(36.47-67.81)\end{array}$ & $\begin{array}{l}42.23 \%(25.27- \\
58.26)\end{array}$ & \\
\hline & Minor MM & $\begin{array}{l}\text { 63.06\% (39.29- } \\
79.65)\end{array}$ & $\begin{array}{l}54.05 \%(28.17- \\
74.17)\end{array}$ & & $\begin{array}{l}45.70 \% \\
(24.45-64.71)\end{array}$ & $\begin{array}{l}29.38 \%(9.70- \\
52.57)\end{array}$ & \\
\hline \multirow[t]{2}{*}{ Donor age (year) } & $\leq 30$ & $\begin{array}{l}80.85 \% \text { (72.29- } \\
87.0)\end{array}$ & $\begin{array}{l}71.63 \% \text { (61.34- } \\
79.63)\end{array}$ & \multirow[t]{2}{*}{0.308} & $\begin{array}{l}61.43 \% \\
(51.84-69.67) \\
\end{array}$ & $\begin{array}{l}45.04 \% \text { (34.74- } \\
54.80)\end{array}$ & \multirow[t]{2}{*}{0.872} \\
\hline & $>30$ & $\begin{array}{l}72.95 \% \text { (57.90- } \\
83.36)\end{array}$ & $\begin{array}{l}62.48 \%(45.0- \\
75.80)\end{array}$ & & $\begin{array}{l}55.47 \% \\
(39.99-68.46)\end{array}$ & $\begin{array}{l}42.13 \% \text { (26.19- } \\
57.25)\end{array}$ & \\
\hline $\begin{array}{l}{\text { CD } 34^{+} \text {Cell dose }} \\
\text { infused }\end{array}$ & $\leq 6$ & $\begin{array}{l}76.53 \% \text { (67.61- } \\
83.30)\end{array}$ & $\begin{array}{l}66.88 \%(56.65- \\
75.22) \\
\end{array}$ & 0.654 & $\begin{array}{l}55.43 \% \\
(45.74-64.08) \\
\end{array}$ & $\begin{array}{l}42.85 \%(33.01- \\
52.30)\end{array}$ & 0.593 \\
\hline
\end{tabular}




\begin{tabular}{|c|c|c|c|c|c|c|c|}
\hline \multirow[t]{2}{*}{$\left(\times 10^{6} / \mathrm{kg}\right)$} & $6-8$ & $\begin{array}{l}77.19 \%(57.40- \\
88 . .62)\end{array}$ & $\begin{array}{l}77.19 \%(57.40- \\
88 . .62)\end{array}$ & & $\begin{array}{l}68.24 \% \\
(48.41-81.77)\end{array}$ & $\begin{array}{l}49.63 \%(27.06- \\
68.70)\end{array}$ & \\
\hline & $>8$ & $\begin{array}{l}92.31 \%(56.64- \\
98.88)\end{array}$ & $\begin{array}{l}63.30 \%(21.45- \\
87.30)\end{array}$ & & $\begin{array}{l}68.32 \% \\
(39.69-85.47)\end{array}$ & $\begin{array}{l}42.70 \%(12.82- \\
70.29)\end{array}$ & \\
\hline \multirow{2}{*}{$\begin{array}{l}\text { CD3 }^{+} \text {Cell dose } \\
\text { infused } \\
\left(\times 10^{6} / \mathrm{kg}\right)\end{array}$} & $\leq 250$ & $\begin{array}{l}73.48 \% \text { (61.48- } \\
82.27)\end{array}$ & $\begin{array}{l}66.13 \%(52.09- \\
76.94)\end{array}$ & \multirow[t]{2}{*}{0.446} & $\begin{array}{l}60.14 \% \\
(47.81-70.44)\end{array}$ & $\begin{array}{l}39.51 \%(25.91- \\
52.80)\end{array}$ & \multirow[t]{2}{*}{0.601} \\
\hline & $>250$ & $\begin{array}{l}81.91 \%(72.07- \\
88.55)\end{array}$ & $\begin{array}{l}69.97 \%(57.74- \\
79.27)\end{array}$ & & $\begin{array}{l}58.26 \% \\
(47.10-67.86)\end{array}$ & $\begin{array}{l}47.20 \%(35.68- \\
57.88)\end{array}$ & \\
\hline
\end{tabular}

ALL: acute lymphoblastic leukemia, AML: acute myeloblastic leukemia, BM: bone marrow, BM+: involvement of bone marrow together with other sites, CR: complete remission, GFRFS: GvHD-free/relapse-free survival, Haplo: HLA-haploidentical donors, MM: mismatched, MRD/MMRD: HLA-matched related and HLA-mismatched related donors, MUDMMUD: HLA-matched unrelated and HLA-mismatched unrelated donors, OS: overall survival, R/D: recipient/donor, WBC: white blood cell.

Table 5. Covariates with significant impact in Cox analysis of RI and NRM 


\begin{tabular}{|c|c|c|c|c|c|c|c|c|c|c|c|c|c|}
\hline & & \multicolumn{6}{|c|}{ RI } & \multicolumn{6}{|c|}{ NRM } \\
\hline & & \multicolumn{3}{|c|}{ Univariate } & \multicolumn{3}{|c|}{ Multivariate } & \multicolumn{3}{|c|}{ Univariate } & \multicolumn{3}{|c|}{ Multivariate } \\
\hline & & $\mathrm{HR}$ & \begin{tabular}{|l|}
$95 \%$ \\
CI \\
\end{tabular} & $\begin{array}{l}\mathrm{P} \text { - } \\
\text { value }\end{array}$ & $\mathrm{HR}$ & $\begin{array}{l}95 \% \\
\text { CI }\end{array}$ & $\begin{array}{l}\text { P- } \\
\text { value }\end{array}$ & $\mathrm{HR}$ & $\begin{array}{l}95 \% \\
\text { CI }\end{array}$ & $\begin{array}{l}\text { P- } \\
\text { value }\end{array}$ & $\mathrm{HR}$ & $\begin{array}{l}95 \% \\
\text { CI }\end{array}$ & $\begin{array}{l}\mathrm{P} \text { - } \\
\text { value }\end{array}$ \\
\hline \multirow[t]{3}{*}{ Donor type } & Haplo & 1.00 & & \multirow[t]{3}{*}{0.893} & 1.00 & & & 1.00 & & \multirow[t]{3}{*}{0.001} & 1.00 & & \\
\hline & MUD/MMUD & 0.85 & \begin{tabular}{|l|}
$(0.43-$ \\
$1.66)$ \\
\end{tabular} & & 0.90 & $\begin{array}{l}(0.37- \\
2.19) \\
\end{array}$ & 0.826 & 1.98 & $\begin{array}{l}(0.78- \\
4.99) \\
\end{array}$ & & 6.18 & $\begin{array}{l}(1.98- \\
19.26)\end{array}$ & 0.002 \\
\hline & MRD/MMRD & 0.92 & \begin{tabular}{|l|}
$(0.57-$ \\
$1.48)$ \\
\end{tabular} & & 0.76 & $\begin{array}{l}(0.42- \\
1.38) \\
\end{array}$ & 0.371 & 0.27 & $\begin{array}{l}(0.09- \\
0.77) \\
\end{array}$ & & 0.49 & $\begin{array}{l}(0.15- \\
1.56) \\
\end{array}$ & 0.230 \\
\hline \multirow{3}{*}{$\begin{array}{l}\text { Leukemia } \\
\text { type }\end{array}$} & B-ALL & 1.00 & & \multirow[t]{3}{*}{0.001} & 1.00 & & & 1.00 & & \multirow[t]{3}{*}{0.404} & & & \\
\hline & T-ALL & 2.20 & \begin{tabular}{|l}
$(1.27-$ \\
$3.81)$ \\
\end{tabular} & & 2.04 & $\begin{array}{l}(0.95- \\
4.36) \\
\end{array}$ & 0.064 & 0.54 & $\begin{array}{l}(0.12- \\
2.34) \\
\end{array}$ & & & & \\
\hline & AML & 0.57 & \begin{tabular}{|l}
$(0.36-$ \\
$0.92)$ \\
\end{tabular} & & 0.35 & $\begin{array}{l}(0.10- \\
1.14) \\
\end{array}$ & 0.082 & 0.56 & $\begin{array}{l}(0.22- \\
1.44) \\
\end{array}$ & & & & \\
\hline \multirow[t]{2}{*}{ Gender } & Female & 1.00 & & \multirow[t]{2}{*}{0.004} & 1.00 & & & 1.00 & & \multirow[t]{2}{*}{0.368} & & & \\
\hline & Male & 1.97 & \begin{tabular}{|l}
$(1.23-$ \\
$3.14)$ \\
\end{tabular} & & 2.83 & $\begin{array}{l}(1.37- \\
5.84) \\
\end{array}$ & 0.005 & 0.69 & $\begin{array}{l}(0.30- \\
1.54) \\
\end{array}$ & & & & \\
\hline \multirow{3}{*}{$\begin{array}{l}\text { WBC at } \\
\text { diagnosis } \\
\left(\times 10^{9} / 1\right)\end{array}$} & $\leq 50$ & 1.00 & & \multirow[t]{3}{*}{0.012} & 1.00 & & & 1.00 & & \multirow[t]{3}{*}{0.521} & & & \\
\hline & $50-100$ & 1.83 & \begin{tabular}{|l}
$(0.88-$ \\
$3.79)$ \\
\end{tabular} & & 1.95 & $\begin{array}{l}(0.77- \\
4.91) \\
\end{array}$ & 0.156 & 2.00 & $\begin{array}{l}(0.60- \\
6.65) \\
\end{array}$ & & & & \\
\hline & $>100$ & 2.21 & \begin{tabular}{|l}
$1.22-$ \\
$4.0)$ \\
\end{tabular} & & 1.99 & $\begin{array}{l}(0.92- \\
4.17) \\
\end{array}$ & 0.078 & 1.18 & $\begin{array}{l}(0.35- \\
3.94) \\
\end{array}$ & & & & \\
\hline \multirow{3}{*}{$\begin{array}{l}\text { Disease } \\
\text { status at } \\
\text { HSCT }\end{array}$} & CR1 & 1.00 & & \multirow[t]{3}{*}{0.004} & 1.00 & & & 1.00 & & \multirow[t]{3}{*}{0.104} & 1.00 & & \\
\hline & CR2 & 1.84 & \begin{tabular}{|l|}
$(1.22-$ \\
$2.80)$ \\
\end{tabular} & & 2.60 & $\begin{array}{l}(1.01- \\
6.65)\end{array}$ & 0.046 & 2.47 & $\begin{array}{l}(1.03- \\
5.90)\end{array}$ & & 14.30 & $\begin{array}{l}(3.16- \\
64.6)\end{array}$ & 0.001 \\
\hline & CR3+ & 1.12 & $\begin{array}{l}(0.56- \\
2.24) \\
\end{array}$ & & 0.59 & $\begin{array}{l}(0.09- \\
3.7)\end{array}$ & 0.575 & 1.16 & $\begin{array}{l}(0.24- \\
5.60)\end{array}$ & & 4.29 & $\begin{array}{l}(0.39- \\
46.6)\end{array}$ & 0.231 \\
\hline \multirow{3}{*}{$\begin{array}{l}\text { Relapse } \\
\text { location }\end{array}$} & No relapse & 1.00 & & \multirow[t]{3}{*}{0.001} & 1.00 & & & 1.00 & & \multirow[t]{3}{*}{0.272} & 1.00 & & \\
\hline & $\mathrm{BM} / \mathrm{BM}+$ & 1.33 & \begin{tabular}{|l|}
$(0.85-$ \\
$2.09)$ \\
\end{tabular} & & 0.61 & $\begin{array}{l}(0.26- \\
1.43) \\
\end{array}$ & 0.258 & 1.85 & $\begin{array}{l}(0.79- \\
4.31)\end{array}$ & & 0.24 & $\begin{array}{l}0.07- \\
0.79)\end{array}$ & 0.020 \\
\hline & Extramedullary & 3.02 & \begin{tabular}{|l|}
$(1.77-$ \\
$5.17)$ \\
\end{tabular} & & 1.00 & & & 0.79 & $\begin{array}{l}(0.17- \\
3.60) \\
\end{array}$ & & 0.12 & $\begin{array}{l}(0.02- \\
0.77) \\
\end{array}$ & 0.025 \\
\hline \multirow{2}{*}{$\begin{array}{l}\text { Age at } \\
\text { HSCT } \\
\text { (year) }\end{array}$} & $\leq 15$ & 1.00 & & \multirow[t]{2}{*}{0.390} & & & & 1.00 & & \multirow[t]{2}{*}{0.001} & 1.00 & & \\
\hline & $>15$ & 0.82 & $\begin{array}{l}(0.53- \\
1.28)\end{array}$ & & & & & 4.94 & $\begin{array}{l}(2.10- \\
11.5)\end{array}$ & & 8.80 & $\begin{array}{l}(2.82- \\
27.4)\end{array}$ & 0.001 \\
\hline \multirow{2}{*}{$\begin{array}{l}\text { Donor age } \\
\text { (year) }\end{array}$} & $\leq 30$ & 1.00 & & \multirow[t]{2}{*}{0.771} & & & & 1.00 & & \multirow[t]{2}{*}{0.188} & 1.00 & & \\
\hline & $>30$ & 1.06 & $\begin{array}{l}(0.69- \\
1.63)\end{array}$ & & & & & 1.70 & $\begin{array}{l}(0.76- \\
3.80)\end{array}$ & & 0.65 & $\begin{array}{l}(0.22- \\
1.94)\end{array}$ & 0.451 \\
\hline
\end{tabular}

ALL: acute lymphoblastic leukemia, AML: acute myeloblastic leukemia, BM: bone marrow, BM+: involvement of bone marrow together with other sites, CR: complete remission, Haplo: HLA-haploidentical donors, MRD/MMRD: HLA-matched related and HLAmismatched related donors, MUDMMUD: HLA-matched unrelated and HLA-mismatched unrelated donors, NRM: non-relapse mortality, RI: relapse incidence, WBC: white blood cell.

Table 6 Covariates with significant impact in Cox analysis of OS and GFRFS 


\begin{tabular}{|c|c|c|c|c|c|c|c|c|c|c|c|c|c|}
\hline & & \multicolumn{6}{|c|}{ OS } & \multicolumn{6}{|c|}{ GFRFS } \\
\hline & & \multicolumn{3}{|c|}{ Univariate } & \multicolumn{3}{|c|}{ Multivariate } & \multicolumn{3}{|c|}{ Univariate } & \multicolumn{3}{|c|}{ Multivariate } \\
\hline & & HR & $\begin{array}{l}95 \% \\
\text { CI }\end{array}$ & $\begin{array}{l}\mathrm{P}- \\
\text { value }\end{array}$ & HR & $\begin{array}{l}95 \% \\
\text { CI }\end{array}$ & $\begin{array}{l}\mathrm{P} \text { - } \\
\text { value }\end{array}$ & HR & $\begin{array}{l}95 \% \\
\text { CI }\end{array}$ & $\begin{array}{l}\mathrm{P}- \\
\text { value }\end{array}$ & HR & $\begin{array}{l}95 \% \\
\text { CI }\end{array}$ & $\begin{array}{l}\mathrm{P}- \\
\text { value }\end{array}$ \\
\hline \multirow[t]{3}{*}{ Donor type } & Haplo & 1.00 & & \multirow[t]{3}{*}{0.190} & 1.00 & & & 1.00 & & \multirow[t]{3}{*}{0.428} & 1.00 & & \\
\hline & MUD/MMUD & 1.48 & $\begin{array}{l}(0.61- \\
3.56)\end{array}$ & & 3.59 & $\begin{array}{l}(0.97- \\
13.2)\end{array}$ & 0.055 & 1.42 & $\begin{array}{l}(0.71- \\
2.86)\end{array}$ & & 2.66 & $\begin{array}{l}(1.02- \\
6.90)\end{array}$ & 0.044 \\
\hline & MRD/MMRD & 0.73 & $\begin{array}{l}(0.34- \\
1.53)\end{array}$ & & 1.12 & $\begin{array}{l}(0.34- \\
3.67)\end{array}$ & 0.843 & 0.96 & $\begin{array}{l}(0.55- \\
1.67)\end{array}$ & & 1.22 & $\begin{array}{l}(0.55- \\
2.70)\end{array}$ & 0.620 \\
\hline \multirow{3}{*}{$\begin{array}{l}\text { Leukemia } \\
\text { type }\end{array}$} & B-ALL & 1.00 & & \multirow[t]{3}{*}{0.003} & 1.00 & & & 1.00 & & \multirow[t]{3}{*}{0.036} & 1.00 & & \\
\hline & T-ALL & 1.90 & $\begin{array}{l}(0.89- \\
4.07)\end{array}$ & & 2.06 & $\begin{array}{l}(0.68- \\
6.17)\end{array}$ & 0.195 & 1.49 & $\begin{array}{l}(0.78- \\
2.81)\end{array}$ & & 1.00 & $\begin{array}{l}(0.39- \\
2.57)\end{array}$ & 0.994 \\
\hline & AML & 0.39 & $\begin{array}{l}(0.17- \\
0.86)\end{array}$ & & 0.19 & $\begin{array}{l}(0.03- \\
0.94)\end{array}$ & 0.042 & 0.62 & $\begin{array}{l}(0.37- \\
1.02)\end{array}$ & & 0.44 & $\begin{array}{l}(0.19- \\
1.02)\end{array}$ & 0.057 \\
\hline \multirow[t]{2}{*}{ Gender } & Female & 1.00 & & \multirow[t]{2}{*}{0.169} & 1.00 & & & 1.00 & & \multirow[t]{2}{*}{0.045} & 1.00 & & \\
\hline & Male & 1.58 & $\begin{array}{l}(0.80- \\
3.14)\end{array}$ & & 1.88 & $\begin{array}{l}(0.67- \\
5.25)\end{array}$ & 0.228 & 1.62 & $\begin{array}{l}(0.99- \\
2.64)\end{array}$ & & 1.70 & $\begin{array}{l}(0.83- \\
3.47)\end{array}$ & 0.142 \\
\hline \multirow{3}{*}{$\begin{array}{l}\text { WBC at } \\
\text { diagnosis ( } \times \\
\left.10^{9} / 1\right)\end{array}$} & $\leq 50$ & 1.00 & & \multirow[t]{3}{*}{0.200} & 1.00 & & & 1.00 & & \multirow[t]{3}{*}{0.191} & 1.00 & & \\
\hline & $50-100$ & 2.54 & $\begin{array}{l}(0.94- \\
6.90)\end{array}$ & & 3.68 & $\begin{array}{l}(1.24- \\
10.9)\end{array}$ & 0.019 & 1.71 & $\begin{array}{l}(0.80- \\
3.68)\end{array}$ & & 2.12 & $\begin{array}{l}(0.95- \\
4.73)\end{array}$ & 0.064 \\
\hline & $>100$ & 1.56 & $\begin{array}{l}(0.60- \\
4.03) \\
\end{array}$ & & 1.99 & $\begin{array}{l}(0.68- \\
5.84) \\
\end{array}$ & 0.208 & 1.67 & $\begin{array}{l}(0.88- \\
3.17) \\
\end{array}$ & & 2.01 & $\begin{array}{l}(0.98- \\
4.12) \\
\end{array}$ & 0.054 \\
\hline \multirow{3}{*}{$\begin{array}{l}\text { Disease } \\
\text { status at } \\
\text { HSCT }\end{array}$} & CR1 & 1.00 & & \multirow[t]{3}{*}{0.004} & 1.00 & & & 1.00 & & \multirow[t]{3}{*}{0.052} & 1.00 & & \\
\hline & CR2 & 2.95 & $\begin{array}{l}(1.52- \\
5.72) \\
\end{array}$ & & 1.05 & $\begin{array}{l}(0.29- \\
3.71) \\
\end{array}$ & 0.938 & 1.77 & $\begin{array}{l}(1.11- \\
2.82) \\
\end{array}$ & & 2.06 & $\begin{array}{l}(0.77- \\
5.50)\end{array}$ & 0.147 \\
\hline & CR3+ & 2.03 & $\begin{array}{l}(0.78- \\
5.29) \\
\end{array}$ & & 0.51 & $\begin{array}{l}(0.07- \\
3.62) \\
\end{array}$ & 0.507 & 1.43 & $\begin{array}{l}(0.71- \\
2.88) \\
\end{array}$ & & 1.60 & $\begin{array}{l}(0.42- \\
6.09) \\
\end{array}$ & 0.485 \\
\hline \multirow{3}{*}{$\begin{array}{l}\text { Relapse } \\
\text { location }\end{array}$} & No relapse & 1.00 & & \multirow[t]{3}{*}{0.011} & 1.00 & & & 1.00 & & \multirow[t]{3}{*}{0.062} & 1.00 & & \\
\hline & $\mathrm{BM} / \mathrm{BM}+$ & 2.33 & $\begin{array}{l}(1.19- \\
4.56)\end{array}$ & & 1.97 & $\begin{array}{l}(0.59- \\
6.58)\end{array}$ & 0.267 & 1.52 & $\begin{array}{l}(0.95- \\
2.45)\end{array}$ & & 1.16 & $\begin{array}{l}(0.47- \\
2.85)\end{array}$ & 0.735 \\
\hline & Extramedullary & 2.87 & $\begin{array}{l}(1.25- \\
6.59)\end{array}$ & & 1.00 & & & 1.99 & $\begin{array}{l}(1.05- \\
3.75)\end{array}$ & & 1.00 & & \\
\hline \multirow{2}{*}{$\begin{array}{l}\text { Age at } \\
\text { HSCT } \\
\text { (year) }\end{array}$} & $\leq 15$ & 1.00 & & \multirow[t]{2}{*}{0.391} & & & & 1.00 & & \multirow[t]{2}{*}{0.009} & 1.00 & & \\
\hline & $>15$ & 1.31 & $\begin{array}{l}(0.70- \\
2.46)\end{array}$ & & & & & 1.85 & $\begin{array}{l}(1.18- \\
2.90)\end{array}$ & & 2.81 & $\begin{array}{l}(1.42- \\
5.54)\end{array}$ & 0.003 \\
\hline \multirow{2}{*}{$\begin{array}{l}\text { Donor age } \\
\text { (year) }\end{array}$} & $\leq 30$ & 1.00 & & \multirow[t]{2}{*}{0.271} & & & & 1.00 & & \multirow[t]{2}{*}{0.817} & & & \\
\hline & $>30$ & 1.42 & $\begin{array}{l}(0.76- \\
2.62)\end{array}$ & & & & & 1.05 & $\begin{array}{l}(0.66- \\
1.69)\end{array}$ & & & & \\
\hline
\end{tabular}

ALL: acute lymphoblastic leukemia, AML: acute myeloblastic leukemia, BM: bone marrow, BM+: involvement of bone marrow together with other sites, CR: complete remission, GFRFS: GvHD-free/relapse-free survival, Haplo: HLA-haploidentical donors, MM: mismatched, MRD/MMRD: HLA-matched related and HLA-mismatched related donors, MUDMMUD: HLA-matched unrelated and HLA-mismatched unrelated donors, OS: overall survival, WBC: white blood cell.

\section{Figures}



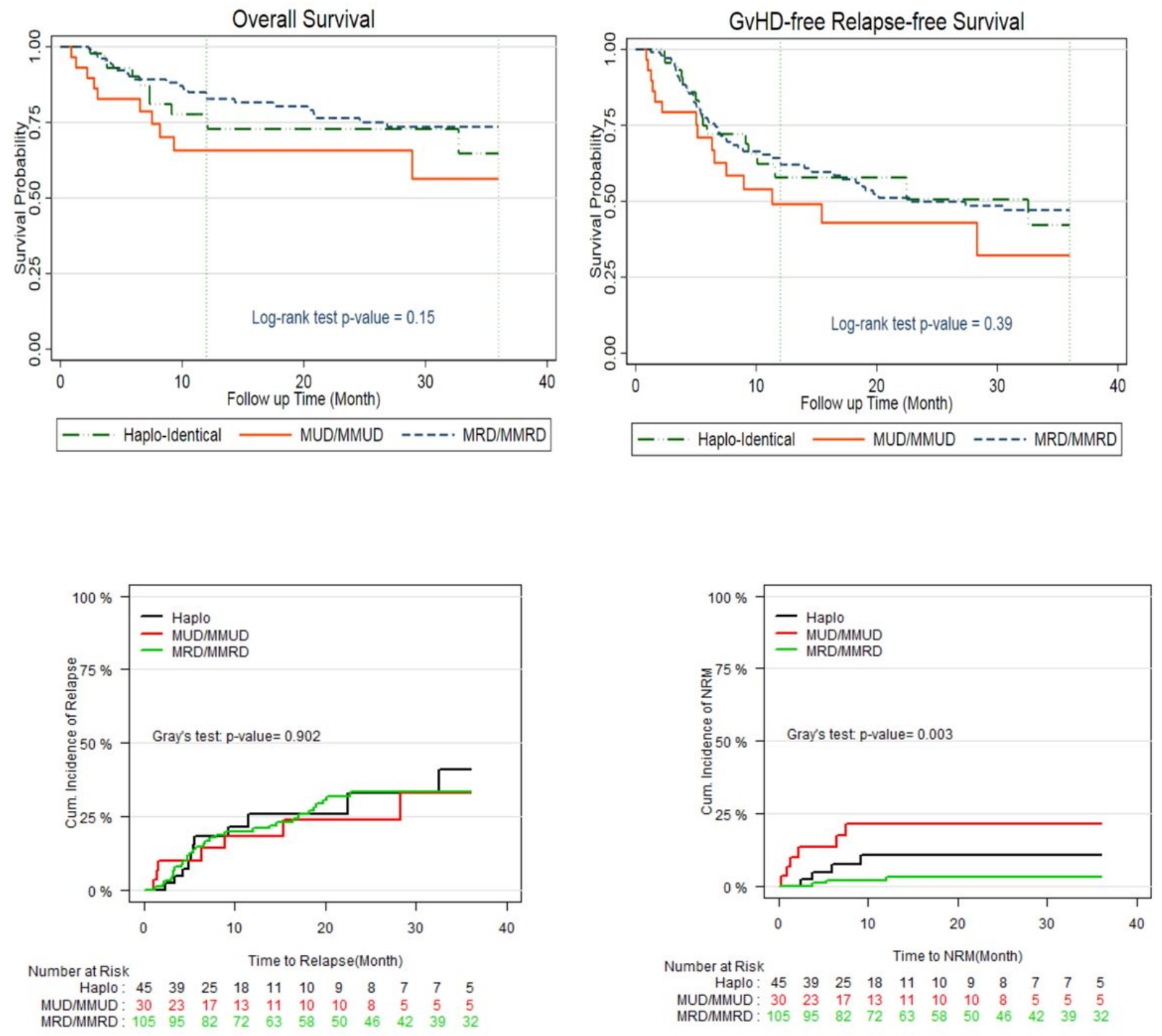

Figure 1

A. Overall survival, B. GvHD-free Relapse-free survival, C. Relapse incidence, D. Non-relapse mortality of patients included in the study. (Haplo: HLA-haploidentical donors, MRD/MMRD: HLA-matched related and HLA-mismatched related donors, MUDMMUD: HLA-matched unrelated and HLA-mismatched unrelated donors) 